\begin{tabular}{|l|l|l|l|l|}
\hline ACTA CARSOLOGICA & $32 / 1$ & 11 & $145-155$ & LJUBLJANA 2003 \\
\hline
\end{tabular}

\title{
KARST AND VAUCLUSE SPRINGS FROM THE POLISH TATRA MTS. RESULTS OF LONG-TERM STATIONARY INVESTIGATIONS
}

\author{
KRAŠKI IN VOKLIŠKI IZVIRI V POLJSKIH TATRAH - \\ IZSLEDKI VEČLETNIH OPAZOVANJ
}

GRZEGORZ BARCZYK ${ }^{1}$

${ }^{1}$ University of Warsaw, Institute of Hydrogeology, Al. Ż wirki i Wigury 93, WARSAW, POLAND, e-mail: gb59@geo.uw.edu.pl 


\begin{abstract}
UDC: 556.3:551.44(438)

Grzegorz Barczyk: Karst and vaucluse springs from the Polish Tatra Mts. Results of long-term stationary investigations
\end{abstract}

Karst (vaucluse) springs, transporting water from fissure-karst systems, result from karst development in the area. At the same time, they are the main source of information on the hydrography of the investigated karst area. Continuous monitoring of groundwaters and surface waters in the Tatra Mountains in Poland takes place for a long time. In the mid-70-ties, the team of Prof. D. Małecka organized an observation network, with water marks along the main Tatra streams right to their outlets from the massif, and with observation points of the largest springs and vaucluse springs. Readings from water marks were collected several times each month by the observers (usually Tatra National Park employees). In 1998 the National Committee for Scientific Research approved a three-year research project entitled: "Determination of retention abilities and the dynamics of denudation in the karst areas of the Polish Tatra Mountains basing on stationary investigations of vaucluse springs". In accordance with this project, between November and December 1998 automatic limnimeters were installed in selected vaucluse (five) springs.

Key words: Tatra Mts., karst area, stationary observations, karst springs.

Izvleček

UDK: 556.3:551.44(438)

\title{
Grzegorz Barczyk: Kraški in vokliški izviri v poljskih Tatrah - izsledki večletnih opazovanj
}

Kraški (vokliški) izviri, ki dovajajo vodo iz kraško-razpoklinskega sistema, so nastali z razvojem krasa na tem ozemlju. To so obenem glavni vir hidrografskih podatkov o preučevanem kraškem ozemlju. V Tatrah na Poljskem že dolgo poteka zvezno opazovanje površinskih in podzemeljskih voda. Skupina prof. D. Małecka je sredi 70-tih let zastavila opazovalno mrežo z vodomeri vzdolž najpomembnejših tatranskih vodotokov prav do izvirov in z opazovalnimi mesti na največjih izvirih oziroma vokliških izvirih. Vodomere so večkrat mesečno odčitavali opazovalci (običajno uslužbenci Tatranskega narodnega parka). 1998 je Nacionalni odbor za znanstvene raziskave odobril triletni projekt z naslovom "Ugotavljanje zadrževalnih sposobnosti in hitrost denudacije na krasu poljskih Tater na podlagi opazovanj vokliških izvirov”. Skladno s tem projektom so bili novembra in decembra 1998 nameščeni avtomatski limnimetri na izbrane (pet) vokliške izvire.

Ključne besede: kras, stalna opazovanja, kraški izviri, Tatre, Poljska. 


\section{INTRODUCTION}

Long-term investigations of karst springs have an immense role in hydrogeological investigations of karst areas. Vaucluse springs represent the karst waters regime most completely. Systematic, contemporaneous observations of stationary investigations allow to determine the reaction of springs to climatic features annually as well as multi-annually (Małecka 1993). Particularly important are stationary investigations of vaucluse springs in mountainous areas, as it is practically impossible there to separate the influence of fissure or pore waters from the influence of fissurekarst waters. The main vaucluse springs of the Tatra Mountains occur in the contact zones between the karstifying deposits and the poorly or non-soluble rocks. Continuous monitoring of groundwaters and surface waters in the Tatra Mountains in Poland takes place for a long time. In the mid-70-ties, the team of Prof. D. Małecka organized an observation network, with water marks along the main Tatra streams right to their outlets from the massif, and with observation points of the largest springs and vaucluse springs. Readings from water marks were collected several times each month by the observers (usually Tatra National Park employees). With minor changes, the network is still in operation. Many papers on the hydrology of the Tatras were based on the interpretation of data collected from the network (Małecka 1984, 1985, 1993, 1996, 1997, Małecka \& Humnicki 1989, Humnicki 1992).

In 1998 the National Committee for Scientific Research approved a three-year research project entitled: "Determination of retention abilities and the dynamics of denudation in the karst areas of the Polish Tatra Mountains basing on stationary investigations of vaucluse springs". In accordance with this project, between November and December 1998 automatic limnimeters were installed in selected vaucluse springs (Fig. 1). Since spring 1999, automatic pluviometers have been installed in the Chochołowska valley and on Hala Kondratowa.

\section{TATRA VAUCLUSE SPRINGS}

\section{Chochotowskie spring}

The spring is situated about $30 \mathrm{~m}$ south of Skała Kmietowicza in the Chochołowska Valley, at about $988 \mathrm{~m}$ a.s.l. It flows out from beneath steep slopes built of limestones and bedded dolomites of the lower Sub-Tatric Succession (Middle Triassic). The spring has a form of a small lake with a characteristic funnel - shaped basin (about $1.6 \mathrm{~m}$ deep), from which water ascends in two streaks to the Chochołowski stream.

The main suppliers of the vaucluse spring are karst systems of the Szczelina Chochołowska Jaskinia Rybia caves (Solicki \& Koisar 1973, Rogalski 1984). Different migration times (between the system of sinkoles and the spring) observed for identical water levels are particulary notable. Additionally, hydrogeologic data (Rogalski 1984, Barczyk 1994) point to a c. $20 \%$ supply from surface waters of the Chochołowski stream. The recharge area of the Chochołowskie vaucluse spring lies entirely within the Chochołowski stream groundwater basin and covers about $7 \mathrm{~km}^{2}$ (Barczyk 1994, 1998). Water capacity within the local reservoir supplying the vaucluse spring is estimated at c. $500 \cdot 10^{3} \mathrm{~m}^{3}$ (Rogalski 1984, Barczyk et al. 1999). The mean discharge from the 1980-2000 interval reaches c. 400 1/s (Małecka 1993, Barczyk et al. 2000). Water temperature is generally constant, changing within $4.5-5.0^{\circ} \mathrm{C}$; hydrocarbonate, calcium and magnesium ions pre- 


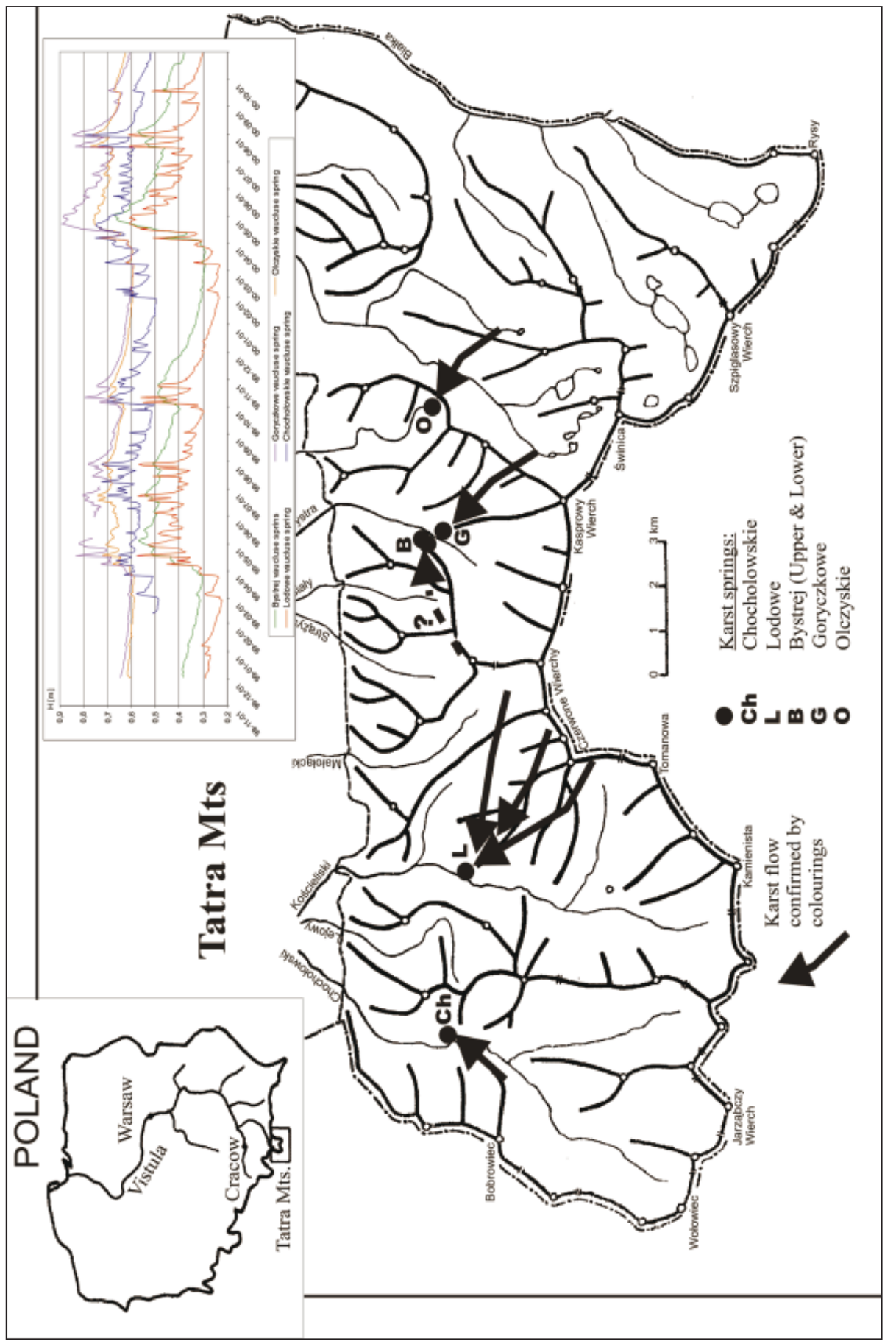

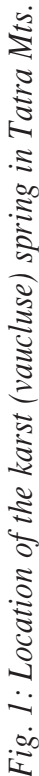


vail in the chemical composition (Małecka 1993, 1997). The carbonate aggressiveness (equilibrium of water with calcite) determined by the saturation index $S_{\text {ic }}$ is -0.77 , and the value of chemical denudation for karst recharge waters reaches c. $30 \mathrm{~m}^{3} / \mathrm{km}^{2}$ per year (Barczyk 1998a, b).

\section{Lodowe spring}

The spring is situated on the eastern side of the Kościeliski stream, about $50 \mathrm{~m}$ from a small bridge on the route to the Mroźna Cave, beneath the valley neck - Brama Kraszewskiego. It ascends from a limestone debris, about $974 \mathrm{~m}$ a.s.l., within the contact zone of the Hightatric and Sub-Tatric successions. The runoff takes place in an area of several tens of $\mathrm{m}^{2}$, creating a small flooding, from which water flows in three arms to the stream. The Lodowe vaucluse spring dewaters the Czerwone Wierchy Massif (Dąbrowski \& Rudnicki 1967). The vaucluse spring recharge area reaches beyond the surface boundary of the Kościeliski stream recharge area, possibly to the south and east, covering an area of c. $17 \mathrm{~km}^{2}$ (Barczyk 1994, 1998). The capacity of water within the local reservoir recharging the vaucluse spring is estimated at $2000 \cdot 10^{3} \mathrm{~m}^{3}$ (Barczyk et al. 1999). Mean discharge in the interval $1980-2000$ is c. $700 \mathrm{l} / \mathrm{s}$. Water temperature is rather stable, at $4.0-4.5^{\circ} \mathrm{C}$; hydrocarbonate and calcium ions prevail in the chemical composition (Małecka 1993, 1997). Carbonate aggressiveness (equilibrium of water with calcite) determined by the saturation index $S_{i c}$ is -0.69 , and the value of chemical denudation for karst recharge waters reaches c. $30 \mathrm{~m}^{3} / \mathrm{km}^{2}$ per year (Barczyk 1998a, b).

\section{Bystre springs - upper and lower}

Both vaucluse springs are present on the western side of the Bystra stream, about $200 \mathrm{~m}$ below its source. They are situated on the eastern slope of the Kalacka Turnia, $50 \mathrm{~m}$ below the tourist track to Hala Kondratowa, about $1180 \mathrm{~m}$ a.s.l. and they are $50 \mathrm{~m}$ apart. Due to a slight difference in height above sea level, the southern runoff is referred to as upper, and the northern one as lower. The lower carries water continuously, while the upper vaucluse spring sporadically dries up. In both cases water descends from rock debris directly into the Bystra stream. The karst system supplying water to the springs developed in carbonate deposits of the Middle Triassic and the Malmian-Neocomian of the Hightatric Succession. The direct recharge area of the springs has not been determined by tracer methods (Rudnicki 1967). Probably the vaucluse springs dewater the Giewont Massif and the area situated southwards (Gała \& Gul 1981, Małecka 1993). The capacity of water in the local reservoir recharging the vaucluse spring is estimated at c. $1200 \cdot 10^{3} \mathrm{~m}^{3}$ (Barczyk et al. 1999). The mean discharge for both springs in the interval $1980-2000$ is c. $350 \mathrm{l} / \mathrm{s}$. Water temperature in both springs varies within $4.0-4.8^{\circ} \mathrm{C}$; hydrocarbonate and calcium ions prevail in the chemical composition (Małecka 1993, 1997). The carbonate aggressiveness (equilibrium of water with calcite) determined by the saturation index $S_{\text {ic }}$ is -1.67 for the upper spring and -1.49 for the lower spring, value of chemical denudation for karst recharge waters reaches (for both of springs) c. $20 \mathrm{~m}^{3} / \mathrm{km}^{2}$ per year (Barczyk 1998b, Wołowiec 2001).

\section{Goryczkowe spring}

The spring is situated on the north-western slopes of the Myślenickie Turnie in the Goryczkowy stream valley, about $1190 \mathrm{~m}$ a.s.l. It flows from a wide (c. $4 \mathrm{~m}$ ) erosional depression within the stream channel. The flow is ascending, particularly notable during lowstands. The recharge area covers probably the karstified Myślenickie Turnie Massif, the alluvial-moraine deposits filling 
the valley, as well as karst systems reaching the Sucha Woda stream drainage basin. The main karst system representing the external circulation (Głazek 1995) is developed in Middle Triassic limestones of the Hightatric Succession. Karst connections between the Goryczkowe vaucluse spring and Sucha Woda drainage basin have been confirmed by several colourings, and the migration of water within the karst systems is dependent on the season and varies between 13 and 24 hours (Dąbrowski \& Głazek 1968, Pachla \& Zaczkiewicz 1985, Małecka 1985, Barczyk \& Humnicki 1999). The capacity of water in the local reservoir recharging the vaucluse spring is estimated at c. $2700 \cdot 10^{3} \mathrm{~m}^{3}$ (Barczyk et al. 1999). The mean discharge in the interval 1980-2000 is c. $800 \mathrm{l} / \mathrm{s}$. Water temperature varies within $4.1-5.4^{\circ} \mathrm{C}$; hydrocarbonate and calcium ions prevail in the chemical composition (Małecka 1993, 1997). The carbonate aggressiveness (equilibrium of water with calcite) determined by the saturation index $\mathrm{S}_{\text {ic }}$ is -1.19 , value of chemical denudation for karst recharge waters reaches (for both of springs) c. $90 \mathrm{~m}^{3} / \mathrm{km}^{2}$ per year (Barczyk 1998b, Wołowiec 2001).

\section{Olczyskie vaucluse spring}

The spring is situated on Polana Olczyska about 1070 m a.s.l., beneath the Skupniów Upłaz on the western side of a large pasture. Till recently, water ascended from a depression of $9 \mathrm{~m}$ in diameter. The depression was filled with limestone debris, sandstone and crystalline rock fragments overlying the Triassic limestones and dolomites of the Sub-Tatric succession. At present the runoff takes place from fissures in a ditch, c. $1.5 \mathrm{~m}$ deep. The vaucluse spring is supplied by karst systems of external circulation from the Sucha Woda valley (Pańszczyca valley). The migration was described by Wrzosek (1933), and confirmed by experimental colourings in the 60-ties and 80-ties. The duration of groundwater flow through systems of karst fissures reaches over 40 hours (Dąbrowski \& Głazek 1968, Pachla \& Zaczkiewicz 1985, Małecka \& Humnicki 1989). Water capacity in the local reservoir recharging the vaucluse spring is estimated at c. $3400 \cdot 10^{3} \mathrm{~m}^{3}$ (Barczyk et al. 1999). The mean capacity in the interval $1980-2000$ is c. $780 \mathrm{l} / \mathrm{s}$. Water temperature varies between 4.2 and $5.1{ }^{\circ} \mathrm{C}$; hydrocarbonate and calcium ions prevail in the chemical composition (Małecka, 1993, 1997). The carbonate aggressiveness (equilibrium of water with calcite) determined by the saturation index $S_{\text {ic }}$ is -0.84 (Barczyk 1998b).

\section{RECESSION CURVE ANALYSIS}

The analysis of recession curves from the autumn-winter periods of Tatra vaucluse springs points to their distinct bipartition (Małecka et al. 1985, Barczyk 1993, 1994, 1997) with completely different angles of the curve gradient. The assumption that the steep segment may correspond to the decline curve and the gentle segment to the recession curve allows to interpret this bipartition as the existence of two separate alimentation areas, being however in contact with one another. According to this interpretation the steep segment would correspond to a local reservoir, while the gentle segment to a regional reservoir. This assumption seems perfectly correct, particularly in light of the noted karst runoffs recharging each of the vaucluse springs from distant areas (Tab. 1). In the recession curve analysis of the described vaucluse springs the curves can be mathematically expressed by the Mangin equation (Mangin 1975). Particular attention has to be drawn to the $\mathrm{Q}_{\mathrm{RO}}$ parameter characterizing the initial discharge of the regional reservoir (Tab. 2). 
Table 1: Characteristic of main Tatra vaucluse springs.

\begin{tabular}{|c|c|c|c|c|c|}
\hline spring & stream & $\begin{array}{l}\text { altitude } \\
\text { [m a.s.l.] }\end{array}$ & $\begin{array}{l}\text { outflow } \\
\text { type }\end{array}$ & geology & recharge area/karst flows \\
\hline Chochołowskie & Chochołowski & above 988 & $\begin{array}{c}\text { ascent } \\
(+20 \% \\
\text { recharge } \\
\text { from stream })\end{array}$ & $\begin{array}{l}\text { outfllow from } \\
\text { limestones and } \\
\text { dolomites of the lower } \\
\text { Sub-Tatric Succesion }\end{array}$ & $\begin{array}{l}\text { recharge from Chochołowski } \\
\text { stream drainage basin }\left(\text { ca. } 7 \mathrm{~km}^{2}\right) \\
\text { Documented karst connections } \\
\text { with Jaskinia Rybia and } \\
\text { Szczelina Chochołowska caves. }\end{array}$ \\
\hline Lodowe & Kościeliski & above 974 & ascent & $\begin{array}{l}\text { outflow in contact } \\
\text { zone of the Sub-Tatric } \\
\text { and Hightatric } \\
\text { succesions }\end{array}$ & $\begin{array}{l}\text { recharge from Czerwone Wierchy } \\
\text { massif (ca. } 17 \mathrm{~km}^{2} \text { ). Documented } \\
\text { connections with Śnież na, } \\
\text { Czarna and Miętusia caves }\end{array}$ \\
\hline $\begin{array}{l}\text { Bystre } \\
\text { (Upper \& } \\
\text { Lower) }\end{array}$ & Bystra & above 1180 & descent & $\begin{array}{l}\text { karst system in } \\
\text { Triassic deposits of the } \\
\text { Hightatric Succesion }\end{array}$ & $\begin{array}{l}\text { probable recharge from } \\
\text { Giewont massif, connections } \\
\text { with Bystra and Kalacka caves }\end{array}$ \\
\hline Goryczkowe & Goryczkowy & above 1185 & ascent & $\begin{array}{l}\text { karst system in } \\
\text { Triassic deposits of the } \\
\text { Hightatric Succesion }\end{array}$ & $\begin{array}{l}\text { recharge by karst systems from } \\
\text { beyond the Goryczkowy stream } \\
\text { drainage basin, that is from the } \\
\text { Sucha Woda drainage basin }\end{array}$ \\
\hline Olczyskie & Olczyski & above 1070 & ascent & $\begin{array}{l}\text { outflow from rocks } \\
\text { lying on limestones } \\
\text { and dolomites of the } \\
\text { Sub-Tatric Succesion }\end{array}$ & $\begin{array}{l}\text { recharge by karst areas from } \\
\text { beyond the Olczyski stream } \\
\text { drainage basin, that is from the } \\
\text { Pańszczycki stream drainage } \\
\text { basin (Sucha Woda valley) }\end{array}$ \\
\hline
\end{tabular}

Table 2: Comparsion between average $Q_{R O}$ and $Q_{\min }\left[\right.$ in $\left.\mathrm{dm}^{3} / \mathrm{s}\right]$.

\begin{tabular}{|c|c|c|c|}
\hline spring & $\begin{array}{c}\text { mean value of } \mathrm{Q}_{\mathrm{R} 0} \\
\text { (years 1980-97) }\end{array}$ & $\begin{array}{c}\text { mean value of } \mathrm{Q}_{\mathrm{R} 0} \\
\text { (years 1998-2001) }\end{array}$ & $\begin{array}{c}\text { mean minimal } \\
\text { discharge }\left(\mathrm{Q}_{\text {min }} \text { ) for }\right. \\
\text { selected periods }\end{array}$ \\
\hline Chochołowskie & 290 & 270 & 220 \\
\hline Lodowe & 302 & 435 & 183 \\
\hline Bystre (Upper \& Lower) & 179 & 227 & 89 \\
\hline Goryczkowe & 252 & 263 & 166 \\
\hline Olczyskie & 278 & 447 & \\
\hline
\end{tabular}

Following the presented interpretation of the recession curves bipartition, the parameter can be treated as a distant area, drained by vaucluse springs during the minimal recharge (winter period). The regional reservoir is therefore common for all vaucluse springs. The area recharging vaucluse springs during periods with large precipitation (from spring to autumn), separate for each vaucluse spring, can be treated as the local reservoir. In this interpretation the value of $\mathrm{Q}_{\mathrm{RO}}$ would corre- 
Table 3: Volumes of water stored up in local and regional groundwater reservoirs calculated by Mangine formula.

\begin{tabular}{|l|c|c|}
\hline vaucluse spring & $\begin{array}{c}\text { average volume of water } \\
\text { stored up in local groundwater } \\
\text { reservoir }\left[\mathrm{m}^{3}\right]\end{array}$ & $\begin{array}{c}\text { average volume of water } \\
\text { stored up in regional groundwater } \\
\text { reservoir }\left[\mathrm{m}^{3}\right]\end{array}$ \\
\hline 1. Chochołowskie & 478895 & 17803757 \\
\hline 2. Lodowe & 2060085 & 13321359 \\
\hline 3. Bystre & 1080104 & 5791344 \\
\hline 4. Goryczkowe & 2444023 & 9031340 \\
\hline 5. Olczyskie & 2379230 & 13059859 \\
\hline
\end{tabular}

spond to the terminal discharge, beneath which recharge takes place only from the regional reservoir. In the case of the Chochołowskie, Goryczkowe, Bystre Upper and Lower (jointly) and Olczyskie (in long period 1980-1997) vaucluse springs the values of the terminal discharges $Q_{R O}$ reach the mean values, where as in the Lodowe vaucluse spring they are more diverse. Application of the Mangin formula allows also the estimation of water capacity within local and regional reservoirs. In the Polish Tatra Mts such calculations were carried out only for the Goryczkowe vaucluse spring (Małecka et al. 1985). Comparison of the mean values of capacity for the particular vaucluse springs allows to note several regularities. Volumes of local reservoirs differ significantly depending on the vaucluse spring. The smallest capacity of water - $478895 \mathrm{~m}^{3}$ - contains the reservoir dewatered by the Chochołowskie vaucluse spring. This is in line with the statement that the recharge area of this vaucluse spring occurs entirely within the Chochołowski stream drainage basin and comprises only karst systems within carbonate deposits. Similar to results calculated from the Mangin formula are those presented by Rogalski (1984) for the Chochołowskie vaucluse spring while carrying out tracer investigations in the spring (capacity of water in the reservoir - about $\left.580000 \mathrm{~m}^{3}\right)$ (Tab. 3).

\section{ANNUAL CHANGES OF KARST SPRING LEVELS ON THE BASIS OF LIMNIMETRIC OBSERVATIONS}

Tatra vaucluse springs strongly depend on climatic conditions, particularly on precipitation and air temperature causing spring thawing of the snow cover (Małecka 1993, Barczyk 1994). Many previous papers indicate the strict relationship of the reaction of the Tatra vaucluse springs to climatic conditions, and the according reaction in particular vaucluse springs. This regularity is confirmed by limnimetric observations. According to hydrogram analysis, in all vaucluse springs the lowest levels were noted during the winter months: from January to the first half of March. From the second half of March onwards, the levels increase due to melting of the snow cover. The process rapidly intensifies in April (this pattern may be linked with the determined durations of over 7 days for filling of local basins recharging the vaucluse springs), and in the following 
months the levels depend on precipitation, which radically decreasing in the autumn-winter months create a long-term recession in vaucluse spring discharge. During the maximum filling of the massif (summer period) reaction of the vaucluse spring to rainfall took from 6 to 8 hour. The lowest lowstands take place in the end of winter and are linked with the retention of precipitation in form of snow.

Comparison of factors causing the highest levels of particular vaucluse springs, thus determining their regimes, is quite interesting. In the case of Chochołowskie and Olczyskie vaucluse springs, highest levels result from the summer rainfall, whereas in the Lodowe, Bystra and Goryczkowy vaucluse springs the highest levels occurred during thawing.

The Chochołowskie and Olczyskie vaucluse springs are characterized by a precipitation-thawing regime, whereas the remaining by a thawing-precipitation regime. The according reaction of particular vaucluse springs is confirmed by analysis of the correlation coefficient $r$ in relation to the mean 24-hours level (Tab. 4).

To conclude, the presented detailed investigations on the reaction of the Tatra vaucluse springs to atmospheric conditions would not have been possible without limnimetric observations. The accuracy and large frequency of measurements (every $0.5 \mathrm{~h}$ ) is of large importance in scientific

Table 4: Correlation coefficient r between the mean 24-hour water levels in the vaucluse springs.

\begin{tabular}{|c|c|c|c|c|c|}
\hline \multirow[t]{2}{*}{ vaucluse springs } & $\mathrm{CH}$ & $\mathrm{L}$ & B & $\mathrm{G}$ & $\mathrm{O}$ \\
\hline & \multicolumn{5}{|c|}{ hydrological year 1999} \\
\hline Chochołowskie $(\mathrm{CH})$ & - & 0.77 & 0.57 & 0.71 & 0.72 \\
\hline Lodowe (L) & & - & 0.87 & 0.94 & 0.91 \\
\hline Bystre (B) & & & - & 0.94 & 0.94 \\
\hline Goryczkowe (G) & & & & - & 0.96 \\
\hline \multirow[t]{2}{*}{ Olczyskie $(\mathrm{O})$} & & & & & - \\
\hline & \multicolumn{5}{|c|}{ hydrological year 2000} \\
\hline Chochołowskie $(\mathrm{CH})$ & - & 0.78 & 0.57 & 0.69 & 0.69 \\
\hline Lodowe (L) & & - & 0.90 & 0.96 & 0.95 \\
\hline Bystre (B) & & & - & 0.95 & 0.97 \\
\hline Goryczkowe (G) & & & & - & 0.95 \\
\hline \multirow[t]{2}{*}{ Olczyskie $(\mathrm{O})$} & & & & & - \\
\hline & \multicolumn{5}{|c|}{ hydrological year 2001} \\
\hline Chochołowskie $(\mathrm{CH})$ & - & 0.92 & 0.79 & 0.90 & 0.93 \\
\hline Lodowe (L) & & - & 0.85 & 0.96 & 0.94 \\
\hline Bystre (B) & & & - & 0.91 & 0.86 \\
\hline Goryczkowe (G) & & & & - & 0.97 \\
\hline Olczyskie $(\mathrm{O})$ & & & & & - \\
\hline
\end{tabular}


observations, focused on the determination of the dynamics of surface and groundwaters as well as their hydraulic links in carbonate rocks and fissure-karst massifs, therefore they are crucial in the regional analysis of hydrogeological and hydrological conditions of the entire Western Tatra Mountains.

\section{BIBLIOGRAPHY}

Barczyk, G., 1993: Aplication of Radczuk \& Szarska method of underground flow calculations in mountain karst areas. - In: Współczesne Problemy Hydrogeologii, 6, 341-345, Wrocław. [In Polish]

Barczyk, G., 1994: Karst-fissure waters from Western Tatra Mts. and problems of their protection. - unpublished Ph. D. thesis; Institute of Hydrogeology, University of Warsaw, p. 1-167, Warszawa. [In Polish]

Barczyk, G., 1998: Obserwacje stacjonarne wybranych wywierzysk tatrzańskich. - Przegląd geologiczny, 1 (46), 42-43, Warszawa.

Barczyk, G., 1998a: The carbonate aggressiveness of water in the karst areas of the basin of the Chochołowski and Kościeliski streams (Western Tatra Mts.). - Acta Geologica Polonica, 48 (1), 115-121, Warszawa.

Barczyk, G., 1998b: The stationary field research on chemical denudation of carbonate karst in catchment area of Chochołowski and Kościeliski streams (Western Tatra Mts.). - In: A. Kotarba (Ed.), Physical Geography Study in the Tatra Mountains. III, 25-34, Wrocław. [In Polish]

Barczyk, G. \& Humnicki W., 1999: Influence of massif flooding on the migraton of water in the Goryczkowe vaucluse spring karst system (Tatra Mts.). - In: Współczesne Problemy Hydrogeologii, 9, 21-28, Warszawa. [In Polish]

Barczyk, G. \& Humnicki, W. \& Żurawska. G., 1999: Network of stationary obserwations of the vaucluse springs in the Polish tatra Mts. - In: Współczesne Problemy Hydrogeologii, 9, 385-388, Warszawa. [In Polish]

Barczyk, G. \& Jach, R. \& Nowicki, T., 2000: Kras Doliny Chochołowskiej. - Materiały. 34 Sympozjum Speleologicznego, 9-20, Kościelisko.

Dąbrowski, T. \& J. Rudnicki, 1967: Results of explorations on underground water flows in the Massif of Czerwone Wierchy (Tatra Mountains) (primary reports). - Speleologia. III (1), 31-35, Warszawa. [In Polish]

Dąbrowski, T. \& Głazek, J., 1968: Investigation of the underground karst flows in the Eastern Part of the Polish Tatra Mts. - Speleologia, III (2), 85-98, Warszawa. [In Polish]

Gała, J. \& K. Gul, 1981: Analiza wydajności źródeł i wywierzysk zlewni potoku Bystra pod kątem możliwości ich eksploatacji. - unpublished M. Sc. thesis; Institute of Hydrogeology, University of Warsaw, p. 1-152, Warszawa.

Głazek, J., 1995; Hydrografia krasowa Tatr Polskich. - In: J. Grodzicki (Ed.), Jaskinie Tatrzańskiego Parku Narodowego, 4, 11-30, Warszawa.

Humnicki, W., 1992: Correlation beetwen groundwater and superfical water of the Białka drainage in Tatra Mountains against a background of geological structure. - unpublished Ph. D. thesis; Institute of Hydrogeology, University of Warsaw, p. 1-126, Warszawa. [In Polish] 
Małecka, D., 1984: The Tatra Mountains - an area feeding groundwaters In the Sub-Tatra region. - Parki Narodowe i Rezerwaty Przyrody, 5 (1), 129-147, Białowieża. [In Polish]

Małecka, D., 1985: Studia hydrogeologiczne krasu Tatr Polskich. - Gacek 2, 14-30, Kraków.

Małecka, D., 1993: Hydrogeologia Krasu Tatrzańskiego. - In: J. Grodzicki (Ed.), Jaskinie Tatrzańskiego Parku Narodowego, 3, 11-35, Warszawa.

Małecka, D., 1996: Hydrogeological characteristics of the Tatra Mts.in the light of monitoring. In: A. Kotarba (Ed.), The Tatra National Park - Nature and Man, I, 19-30, Zakopane [In Polish]

Małecka, D., 1997: Springs of the Tatra massif. - Acta Universitatis Lodziensis, 2, 9-25, Łódż. [In Polish]

Małecka, D. \& Humnicki, W., 1989: Role of hydrodynamical conditions in shaping the Olczyska vauclusian spring regime. - Przegląd Geologiczny, 37 (2), 78-84, Warszawa. [In Polish]

Małecka, D. \& Kuberski, D. \& Zaczkiewicz, W., 1985: Hydrogeologiczne problemy wywierzyska Goryczkowego w świetle badań stacjonarnych. - In: Współczesne Problemy Hydrogeologii, 3, 119-131, Kraków.

Mangin, A., 1975: Contribution à l'étude hydrodynamique des aquiferes karstiques. - Ann. Speleol., nr. 29 (3) 283-332, 29 (4) 495-601, 30 (1) 21-124, Moulis.

Pachla, J. \& Zaczkiewicz, W., 1985: Drogi krążenia wód podziemnych zlewni potoku Sucha Woda w Tatrach. - unpublished M. Sc. thesis; Institute of Hydrogeology, University of Warsaw, p. 1-161,. Warszawa.

Rogalski, R., 1984: Studies on ground water flow by the colouring method in the Chochołowska Valley. - Przegląd Geologiczny, 32 (4), 223-225, Warszawa. [In Polish]

Rudnicki, J., 1967: Origin and age of the Western Tatra caverns. - Acta Geologica Polonica, XVII (4), 521-591, Warszawa [In Polish]

Solicki, T. \& Koisar, B., 1973; The Chochołowska Spring enigma. - Taternik, 1, 30-31, Warszawa. [In Polish]

Wołowiec, E., 2001: Wpływ składu chemicznego opadów atmosferycznych na wielkość denudacji chemicznej skał węglanowych zlewni Potoku Bystra (Tatry Polskie). - unpublished M. Sc. thesis; Institute of Hydrogeology, University of Warsaw, p. 1-114, Warszawa.

Wrzosek, A., 1933: Z badań nad zjawiskami krasowemi Tatr Polskich. - Wiadomości Służby Geograficznej 7, 235-270, Warszawa. 